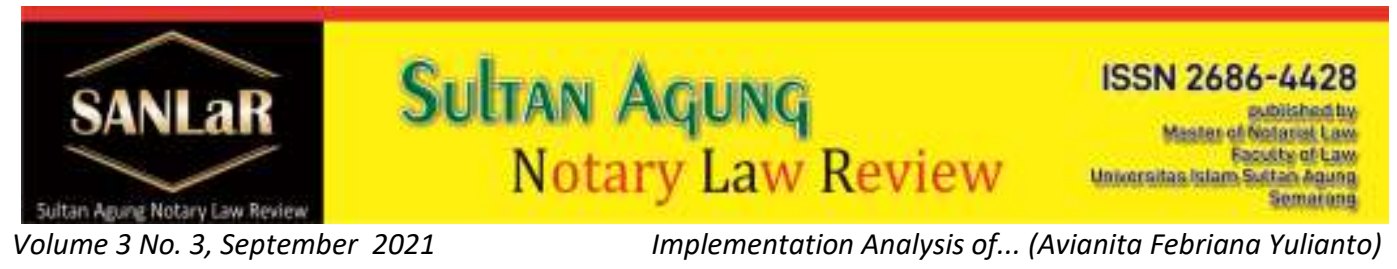

\title{
Implementation Analysis of Improvement of Building Use Rights to Property Rights for Residential Houses
}

\author{
Avianita Febriana Yulianto*) \\ ${ }^{*}$ Faculty of Law, Universitas Islam Sultan Agung (UNISSULA) Semarang, E-mail: \\ avianitafy2021@gmail.com
}

\begin{abstract}
The purpose of this research is to analyze and find out: 1) Implementation of upgrading the status of building use rights to property rights for residential houses at the Cilacap Regency Land Office. 2). Obstacles and solutions in the implementation of increasing the status of Building Use Rights to Property Rights for residential houses at the Cilacap Regency Land Office, namely Petitioners who will register for an increase in land rights for residential houses often do not include an application file with a Building Permit, the public does not know about procedures and conditions that must be attached at the time of submitting an application. To overcome the above constraints, the Cilacap Regency Land Office conducted socialization, this aims to understand information and to straighten people's perceptions who think that upgrading the status of Building Use Rights to Property Rights for residential houses is too complicated and expensive. 2) Obstacles and solutions in the implementation of increasing the status of Building Use Rights to Property Rights for residential houses at the Cilacap Regency Land Office, namely Petitioners who will register for an increase in land rights for residential houses often do not include an application file with a Building Permit, the public does not know about procedures and conditions that must be attached at the time of submitting an application. To overcome the above constraints, the Cilacap Regency Land Office conducted socialization, this aims to understand information and to straighten out public perceptions who consider that upgrading the status of Building Use Rights to Property Rights for residential houses is too complicated and expensive.
\end{abstract}

Keywords: Improved; Status; Rights; Building; Property.

\section{Introduction}

Article 1 paragraph (2) of Government Regulation number 24 of 1997, land parcels are part of the earth's surface which is a limited unit of land and that is all 
that is the object of land registration in Indonesia. ${ }^{1}$ Land has a meaning and at the same time has a dual function, namely social assets, land is a means of binding social unity among the community for life and livelihood, and land as capital asset, namely as a capital factor in development and has grown as a very important economic object as well as a commercial material. and the object of speculation. $^{2}$

Based on the Basic Agrarian Law (UUPA) article 4, land is the surface of the earth whose authority to use it includes the body of the earth, water and the space above it. In this sense, land includes land that already has a right that exists on it and which is attached to a right according to the applicable laws and regulations. ${ }^{3}$ Meanwhile, according to Budi Harsono, he limits the definition of land based on what is meant in Article 4 of the LoGA, that in land law, the word land is used in a juridical sense as an understanding that has been officially demarcated by the LoGA as stated in Article 4 that the right to control from the state is determined by the existence of the law. various rights to the earth's surface called land. ${ }^{4}$ Thus land in a juridical sense can be interpreted as the surface of the earth.

Based on the understanding of land stated above, it can provide an understanding that land has a very high economic value so that it is everyone's obligation to maintain and maintain existence as an object of economic value because land is also useful for the implementation of development, but land also often causes various kinds of problems. for humans so that its use needs to be controlled as well as possible so as not to cause problems in people's lives. ${ }^{5}$

Permanent land rights according to the LoGA are regulated in Article 16, namely: ${ }^{6}$ 1) Permanent land rights, including Ownership Rights (HM), Cultivation Rights (HGU), Use Rights (HP), Lease Rights and Building Use Rights. The right to use the building has a limited period of time, it should be upgraded to the right of ownership in order to have legal certainty for the holder of the right. The increase in HGB to property rights must still be registered at the Land Office where the object is located.

\footnotetext{
${ }^{1}$ Asri Arinda, Pelaksanaan Peralihan Hak Milik Atas Tanah Melalui Hibah Untuk Anak Di Bawah Umur, Jurnal Repertorium Vol. III No. 2 2016, p. 1

2 Achmad Robbie, 2007, Hukum Pengadaan Tanah Untuk Kepentingan Umum, Malang, Bayumedia, p.1

${ }^{3}$ Anonim, 2007, Petunjuk teknis Direktorat Survey dan Potensi Tanah, Deputi Survey, Pengukuran dan Pemetaan BPN RI, Jakarta, p. 6

${ }^{4}$ Boedi, Harsono,1999, Hukum Agraria Indonesia Sejarah Pembentukan UU Pokok Agraria. Djambatan Boedi, Jakarta, p.18

5 John Salindeho, 1993, Masalah Tanah dalam Pembangunan, Sinar Grafika, Jakarta, p.23

6 Ibid, p.16
} 
Cilacap Regency is the largest area in Central Java, its wide area makes Cilacap Regency vulnerable to land disputes, one of which is housing and settlement problems. Houses and land are basic needs for humans who need legal certainty so that land registration must be carried out to obtain land guarantees, while the status of land registered in addition to property rights, there are other lower rights such as HGB, HP, HGU. With lower rights by the community it is deemed inadequate because the period is limited and there is a need for additional costs to extend their rights and their legal position is less strong when compared to Hak Milik (HM).

In Cilacap Regency, many residents have the status of Building Use Rights. Because the HGU only has a limited time, so to prevent future conflicts, considering the population of Cilacap Regency continues to increase, it is better if the HGU for residential houses is upgraded to become property rights in order to have legal certainty for the rights holders. The increase in HGB to Hak Milik must still be registered at the Land Office where the object is located. The National Land Agency (BPN) as the institution that issues land rights certificates, is also authorized to cancel land rights certificates based on the contrarius actus principle. The National Land Agency is a representation of the State in terms of revocation of land rights against individual or institutional rights. ${ }^{7}$

Based on the background of the problem above, the writer is interested in analyzing the thesis problem about waqf with the title"Analysis of the Implementation of the Improvement of Building Use Rights to Property Rights for Residential Houses in Cilacap Regency". This study seeks to answer the implementation of increasing the status of building use rights to become property rights for residential houses at the Cilacap Regency Land Office as well as obstacles and solutions in the implementation of increasing the status of building use rights to property rights for residential houses at the Cilacap Regency Land Office.

The approach method used in this study is a sociological juridical approach. Primary and secondary data sources obtained by interview method and literature review (study document). The data that has been collected both from field research and library research were analyzed using descriptive analysis methods.

\footnotetext{
${ }^{7}$ Mudakir Iskandar Syah, 2014, Pembebasan Tanah Untuk Kepentingan Umum: Upaya Hukum Masyarakat yang Terkena Pembebasan Dan Pencabutan Hak, Penerbit Permata Aksara, Jakarta, p. 3
} 


\section{Results and Discussion}

\subsection{Implementation of the Improvement of the Status of Building Use Rights to Property Rights for Residential Houses at the Cilacap Regency Land Office}

Cilacap Regency is the largest area in Central Java, divided into 24 sub-districts, 269 villages and 15 sub-districts. ${ }^{8}$ In Cilacap Regency, land issues in the era of development and industrialization are increasingly complicated and have the potential to cause turmoil.In Cilacap Regency there is a lot of land that has been built for housing, but most of it is still with the status of Building Use Rights. This is because the development is usually carried out by developers who are none other than parties from Perumnas itself ${ }^{9}$.

An increase in the status of land rights is a government stipulation which confirms that a piece of land which was originally owned with a certain land right, at the request of the right holder, becomes state land and at the same time gives the land to him with other similar new land rights. ${ }^{10}$ The right to use the building has a lower power than the right of ownership. The right to use the building has a limited period of time which will expire at some point. This is contained in Article 35 paragraphs (1) and (2) of the UUPA, so that the holders of building use rights must extend the period of time again, but this is less efficient because the process is long and lengthy at a cost that is not small. In contrast to property rights which are hereditary, strongest, fullest, and have higher legal force than building use rights, so that the holder of property rights no longer needs to extend the term of their land rights. The increasing needs of the community have caused the holders of building use rights to feel the need to increase the status of their land rights to become property rights, especially on land for housing ${ }^{11}$. Community needs that continue to increase can affect the mindset of the community, especially for people who own land that still has the status of building rights. If the term of their land rights has expired or has not yet expired, they choose to immediately submit an application to upgrade the status

\footnotetext{
${ }^{8}$ https://cilacapkab.go.id//, accessed on March 5, 2021 at 21:47 WIB

${ }_{9}$ A Chuasanga, Ong Argo Victoria. (2019). Legal Principles Under Criminal Law in Indonesia and Thailand, Jurnal Daulat Hukum, Vol 2, No 1 (2019) http://jurnal.unissula.ac.id/index.php/RH/article/view/4218 see Deen, Thaufiq., Ong Argo Victoria \& Sumain. (2018). Public Notary Services In Malaysia. JURNAL AKTA: Vol. 5, No. 4, 10171026. Retrieved from http://jurnal.unissula.ac.id/index.php/akta/article/view/4135

${ }^{10}$ Article 1 Paragraph (1) Regulation of the Minister of State for Agrarian Affairs/Head of the National Land Agency Number 5 of 1998 concerning Changes in Building Use Rights or Land Use Rights for Residential Houses encumbered with Mortgage Rights into Ownership Rights.

11 Yaya Kareng, Ong Argo Victoria, R. Juli Moertiyono. (2019). How Notary's Service in Thailand. Sultan Agung Notary Law Review, 1 (1), 46-56, http://jurnal.unissula.ac.id/index.php/SANLaR/article/view/4435
} 
of their land rights to ownership rights rather than just extending the term of their building rights ${ }^{12}$.

Legal basis for upgrading Land Status from Hak Guna Bangunan to Hak Milik:

1. Act No. 5 of 1960

2. Government Regulation Number 24 of 1997

3. Regulation of the Minister of State for Agrarian Affairs/Head of BPN Number 3 of 1997

4. Government Regulation Number 24 of 1997

5. Regulation of the Minister of State for Agrarian Affairs/Head of BPN Number 3 of 1997

6. Government Regulation Number 46 of 2002

7. SE Ka.BPN-600-1900 dated 31 July 2003

As for the definition of Building Use Rights regulated in Article 35 of the BAL, it provides the meaning of Building Use Rights, namely the right to construct and own buildings on land that is not one's own, with a maximum period of 30 years and at the request of the right holder and taking into account the needs or conditions of the building. The building in question can be extended for a maximum period of 20 years. ${ }^{13}$

Conversion of land with building rights property owned by PT developer becomes property rights too done or the status can be changed to proprietary land. Because PT developer is legal entity that is not allowed owning land with the status of property rights, although initially the developer bought land with the status of property rights from citizens public. In the process, the land with SHM status must be lowered the status becomes the right to use the building and then a sale and purchase is made and the name is returned to on PT Developer. Next PT Developer selling buildings with usufructuary status building to consumers. There is PT Developers who directly take care of increased rights to SHM, but not rarely PT developers hand over the management to consumers.

The conditions that must be completed in the process of filing for an increase in Rights from Building Use Rights (HGB) to Ownership Rights (HM) for residential houses are:

a. Original HGB certificate.

12 Ong Argo Victoria, Ade Riusma Ariyana, Devina Arifani. (2020). Code of Ethics and Position of Notary in Indonesia. Sultan Agung Notary Law Review 2 (4), 397-407, http://lppmunissula.com/jurnal.unissula.ac.id/index.php/SANLaR/article/view/13536

${ }^{13}$ Eko Yulian Isnur, 2012, Tata Cara Mengurus Segala Macam Surat Rumah dan Tanah, Jakarta Selatan, PT.Buku Seru, p.11. 
b. Photocopy of Residential Building Permit (IMB) or Building Approval (PBG)

c. Photocopy of SPPT-PBB (Tax Notice Payable Land and Building Tax) for the current year.

d. Photocopy of Applicant's Identity in the form of Identity Card \& Family Card (KTP \& KK).

e. $\quad$ PM 1 from the kelurahan stating that the house is used for housing (in the case that the house does not have an IMB / PBG).

f. Special Power of Attorney, if the management is authorized to a certain party.

The application for an increase in Rights from Building Use Rights (HGB) to Ownership Rights (HM) for land that has an area of more than $600 \mathrm{~m} 2$ is required as a new application for rights, the difference is that the process does not involve Committee A (the right-granting committee consisting of BPN and Kelurahan officers). The process carried out in the Property Rights Application is in the form of a constituting report only at BPN. The output is in the form of a Decree (SK) granting Property Rights.

The costs for managing the increase in rights from Building Use Rights to Ownership Rights are:

a. At the Perumnas Office the official fee is IDR 75,000 and for the unofficial fee of IDR 1,500,000. The process from Perumnas takes 1 to 2 days depending on the leadership then the applicant's files are submitted to the local land office or BPN.

b. Process to the Land Office or BPN for 3 months with an official fee of IDR 300.00 to IDR 400,000 .

C. The management fee collected by the applicant based on the interview is IDR 3,000,000 to IDR 4,000,000

Restrictions on the granting of property rights until now there is no Government Regulation that limits the control of land for housing as referred to in Act No. 56 PIDR 1960. As a step towards that limitation, the granting of Hak Milik on land for residential houses originating from State land is limited as follows:

1. For each area requested, the area should not exceed 2,000 m2 (two thousand square meters).

2. Each applicant is limited to the selection of Ownership Rights on land for residential houses, not more than 5 (five) plots with a total area of 5,000 $\mathrm{m} 2$ (five thousand square meters). ${ }^{14}$

\footnotetext{
${ }^{14}$ Letter of the Minister of State for Agrarian Affairs / Head of the National Land Agency dated June 30, 1998 Number 520-2105, regarding Submission of Decree of the Minister of Agrarian Affairs / Head of the National Land Agency Number 6 of 1998 concerning Granting of Property Rights to Land for Residential Houses, point 4, letter $h$.
} 
One of the weaknesses of the Hak Guna Bangunan (HGB) is that it does not indicate the owner of the land, but only allows the use of the land, such as building a building on land to open a business or a place to live. This certificate also has a term of up to 30 years. After the validity period expires, you must extend it and there is a HGB renewal fee. If not, then the land must be returned to the owner, namely the state, manager, or individual.

The implementation of the increase in land status from Building Use Rights to Property Rights for residential houses as regulated in the Decree of the State Minister of Agrarian Affairs/Head of the National Land Agency Number 6 of 1998 concerning the Granting of Ownership rights to Land for Residential Houses. The application is that each land parcel that is applied for cannot be more than 2000 $\mathrm{m} 2$, this is stated in Article 4 paragraph 2 of the Decree of the State Minister of Agrarian Affairs/Head of the National Land Agency number 6 of 1998. This limitation only applies to applications for Hak Milik which are all or most of the land is used for housing.

The process of implementing the increase in the status of Building Use Rights to Ownership Rights for Residential Houses at the Land Office Cilacap Regencythat is:

1. The applicant must fill out an application for land ownership rights for a residential house at the Land Office Cilacap Regencysubmitted in writing to the Head of the Land Office.

2. The applicant must also attach the certificate of the land concerned in the application for the increase in land rights from Hak Guna Bangunan to Hak Milik because the certificate can provide legal certainty to the holder of the right in question and as legal evidence of ownership.

3. Evidence that must be included in the use of land for residential houses is in the form of:

a. Attach a photocopy of the Permit to Construct a Building from the competent authority stating that the building has been used for residential purposes.

b. A certificate from the village head or sub-district head of the location of the local land that explains that the building is used for residential purposes.

4. The application must be accompanied by attaching a photocopy of the Tax Return Payable (SPPT) and a photocopy of the Land and Building Tax (PBB).

5. For the granting of Hak Milik on land for residential homes, the identity of the applicant used by the applicant must be checked regarding the ownership of the land being applied for. This information is contained in the certificate for which the rights are increased. 
6. There is evidence of the acquisition of rights to the land and building where the building is standing.

7. After all the required documents are complete, then the documents are submitted to counter II (the counter for receiving and submitting technical letters) where the officer examines the documents received. The documents studied are the completeness that is a requirement in the application for land ownership rights for residential houses.

8. After finishing at counter II, the applicant comes to counter III to make payment for the application for land ownership rights. Counter III officers are in charge of making payments for the application.

9. The Head of the Subsidiary for Registration of Rights and Information (PHI) is in charge of examining documents. The document examined is the name of the applicant listed in the identity, is it the same as that contained in the certificate of Hak Guna Bangunan (HGB). If there is a difference in name, the applicant is required to include a statement from the applicant known by the local Village Head. After that, make a disposition or draft a new land book and certificate and cross out the old land book and certificate.

10. After being approved by the Head of Subsidy, the documents and concepts of the land as well as the new certificate are submitted to the Head of the Land Measurement and Registration Section to examine the new land certificate documents and books. If it has been approved, the Head of the Land Measurement and Registration Section will affix the initials to the new land book and certificate, and then forward it to the Head of the Land Office.

11. The Head of the Land Office is in charge of examining the completeness and correctness of the application file as well as examining the documents and concepts of the new land book and certificate. If it has been approved, the Head of the Land Office shall initialize the new land book and certificate. Furthermore, the Head of the Office submits documents and land books as well as certificates to the implementing officer of the PHI subsidy.

12. The PHI subsidy implementing officer keeps the books, then submits the documents to the counter III officer to do the bookkeeping. Then submit the documents to the counter IV officer.

13. The counter IV officer has the duty to record a list of submissions of work results and record the number on the certificate.

14. If it is complete, the officer submits the documents that must be archived to the archive officer, and submits a certificate to the applicant. 
3.2. Obstacles and Solutions in the Implementation of Upgrading the Status of Building Use Rights to Property Rights for Residential Houses at the Cilacap Regency Land Office

In the process of upgrading the status of Hak Guna Bangunan to Hak Milik for residential houses, the Cilacap Regency Land Office encountered several obstacles, namely:

a. Applicants who will register for an increase in land rights for residential houses are often not accompanied by an application file with a Building Permit $(\mathrm{IMB})$ or PBG of the land requested for an increase in rights.

b. The public does not know about the procedures and requirements that must be attached when submitting an application. As a result of this lack of knowledge, it can become an obstacle within the National Land Agency Office in carrying out the improvement procedure, namely the delay in the completion of the increase in Land Rights.

c. Lack of work cooperation between the National Land Agency of Cilacap Regency and the village apparatus in order to educate the people to know more about problems regarding land, especially in increasing the Right to Build into Property Rights.

d. Right dependentsused as collateral for debt. Intended to guarantee the debt of a debtor who gives primary rights to a certain creditor, namely: holder of the mortgage to take precedence over creditors otherwise if the debtor defaults. As it is known that if the usufructuary the building that is used as collateral is written off, the mortgage attached to the right to use the building is also removed.

To overcome the obstacles to increasing the Right to Build into Property Rights for residential houses faced by the Cilacap Regency Land Office, the solutions are: ${ }^{15}$

a. Conducting socialization related to the Transition of Building Use Rights to Property Rights to the public, this aims to understand information and to straighten people's perceptions who think that increasing the status of Building Use Rights to Property Rights for households is too complicated and expensive.

b. Improve facilities and infrastructure to support the performance of the Cilacap Regency Land Office.

\footnotetext{
${ }^{15}$ Interview with Mr. Malik Hasyim, the staff of the Registration of Rights and Information of the Cilacap Regency Land Office, April 2, 2021
} 
c. For mortgages that are used as collateral for debts. The solution for debtors who want to increase the right to use the building to become property right is by paying off the debt to the creditor first so that the building rights agreement which was originally encumbered with mortgage rights can be upgraded to ownership rights. Of course, this is a burdensome choice for the debtor, because the debtor does not necessarily have the funds to pay off the debt immediately. However, this is done for the security of the debtor, because the HGB status will be deleted when upgraded to HM.

\section{Closing}

Based on the description above, the conclusions in writing this thesis are: 1) The implementation of increasing the status of Building Use Rights to Property Rights for residential houses at the Cilacap Regency Land Office, namely submitting an application for Ownership Rights, attaching a land certificate, attaching a photocopy of the Building Permit (IMB) or Building Building Approval (PBG), a statement letter from the Village Head or Kelurahan, attaching a photocopy of the Tax Return Payable (SPPT) and a photocopy of the Land and Building Tax (PBB), checking the Applicant's Identity whether or not it is in accordance with the ownership of the land requested. The next stage is that all documents are submitted to counter II (the counter for receiving and submitting technical letters) where the officer examines the documents received, the applicant comes to counter III to make payments, the Head of Subsidy for Registration of Rights and Information (PHI) is in charge of examining documents, if approved and then submitted to the Head of the Land Measurement and Registration Section to examine the documents and land books for the new certificate, the Head of the Land Office affixes the initials to the new land book and certificate. Furthermore, the Head of the Office submits documents and land books as well as certificates to the $\mathrm{PHI}$ subsidy implementing officer, the $\mathrm{PHI}$ subsidy implementing officer keeps the books, then submits the documents to the counter III officer to do the bookkeeping. Then submit the document to the counter IV officer, the counter IV officer has the duty to record the list of submissions of the work and record the number on the certificate. If it is complete, the officer submits the documents that must be archived to the archive officer, and submits a certificate to the applicant. 2) Obstacles and solutions in the implementation of increasing the status of Hak Guna Bangunan to become Hak Milik for residential houses at the Cilacap Regency Land Office, namely applicants who will register for an increase in land rights for residential houses often do not include an application file, the community does not know about the procedures and requirements required. 


\section{References}

Journals:

[1] A Chuasanga, Ong Argo Victoria. (2019). Legal Principles Under Criminal Law in Indonesia and Thailand, Jurnal Daulat Hukum, Vol 2, No 1 (2019) http://jurnal.unissula.ac.id/index.php/RH/article/view/4218

[2] Asri Arinda, Pelaksanaan Peralihan Hak Milik Atas Tanah Melalui Hibah Untuk Anak Di Bawah Umur, Jurnal Repertorium Vol. III No. 22016

[3] Deen, Thaufiq., Ong Argo Victoria \& Sumain. (2018). Public Notary Services In Malaysia. JURNAL AKTA: Vol. 5, No. 4, 1017-1026. Retrieved from http://jurnal.unissula.ac.id/index.php/akta/article/view/4135

[4] H.M Arba, Implikasi Hukum Peningkatan Status Hak Guna Bangunan (HGB) dan Hak Pakai (HK) Atas Rumah Tinggal Obyek Hak Tanggungan Menjadi Hak Mlik Terhadap Kreditur, Jurnal Hukum JATISWARA 2017 , Fakultas Hukum, Universitas Mataram

[5] Karsono, Amin Purnawan, Pelaksanaan Peningkatan Hak Guna Bangunan Menjadi Hak Milik Untuk Rumah Tinggal di Kantor Pertanahan Kota Pekalongan, Jurnal Akta 2019, Unissula, Semarang

[6] Ong Argo Victoria, Ade Riusma Ariyana, Devina Arifani. (2020). Code of Ethics and Position of Notary in Indonesia. Sultan Agung Notary Law $\begin{array}{lllll}\text { Review } & 2 & (4), & \text { 397-407, } & \underline{\text { htp://lppm- }}\end{array}$ unissula.com/jurnal.unissula.ac.id/index.php/SANLaR/article/view/13536

[7] Yaya Kareng, Ong Argo Victoria, R. Juli Moertiyono. (2019). How Notary's Service in Thailand. Sultan Agung Notary Law Review, 1 (1), 46-56, http://jurnal.unissula.ac.id/index.php/SANLaR/article/view/4435

Books:

[1] Achmad Robbie, 2007, Hukum Pengadaan Tanah Untuk Kepentingan Umum, Malang, Bayumedia

[2] Achmad Robbie, 2007, Hukum Pengadaan Tanah Untuk Kepentingan Umum, Malang, Bayumedia

[3] Adrian Sutedi, 2018, Peralihan Hak Atas Tanah dan Pendaftarannya, cetakan.9, Sinar Grafika, Jakarta

[4] Anonim, 2007, Petunjuk teknis Direktorat Survey dan Potensi Tanah, Deputi Survey, Pengukuran dan Pemetaan BPN RI, Jakarta,h

[5] Boedi Harsono, 2003, Menuju Penyempurnaan Hukum Tanah Nasional, cetakan kedua, Universitas Trisaksi, Jakarta

[6] Boedi, Harsono,1999, Hukum Agraria Indonesia Sejarah Pembentukan UU Pokok Agraria. Djambatan Boedi, Jakarta 
[7] Eko Yulian Isnur, 2012, Tata Cara Mengurus Segala Macam Surat Rumah dan Tanah, Jakarta Selatan, PT.Buku Seru

[8] Eko Yulian Isnur, 2012, Tata Cara Mengurus Segala Macam Surat Rumah dan Tanah, Jakarta Selatan, PT.Buku Seru

[9] John Salindeho, 1993, Masalah Tanah dalam Pembangunan, Sinar Grafika, Jakarta

[10] Mudakir Iskandar Syah, 2014, Pembebasan Tanah Untuk Kepentingan Umum: Upaya Hukum Masyarakat yang Terkena Pembebasan Dan Pencabutan Hak, Penerbit Permata Aksara, Jakarta

[11] Mudakir Iskandar Syah, 2014, Pembebasan Tanah Untuk Kepentingan Umum: Upaya Hukum Masyarakat yang Terkena Pembebasan Dan Pencabutan Hak, Penerbit Permata Aksara, Jakarta

Regulation:

[1] Act No. 4 of 1992 concerning Housing and Settlements

[2] Act No. 5 of 1960 concerning Basic Regulations on Agrarian Principles

[3] Government Regulation No. 40 of 1996 concerning Cultivation Rights, Building Use Rights and Land Use Rights

[4] Letter of the Minister of State for Agrarian Affairs / Head of the National Land Agency dated June 30, 1998 Number 520-2105, regarding Submission of Decree of the Minister of Agrarian Affairs / Head of the National Land Agency Number 6 of 1998 concerning Granting of Property Rights to Land for Residential Houses, point 4, letter $h$.

[5] Regulation of the Minister of State for Agrarian Affairs/Head of the National Land Agency Number 5 of 1998 concerning Changes in Building Use Rights or Land Use Rights for Residential Houses that are encumbered with Mortgage Rights into Ownership Rights.

[6] Urip Santoso, 2010, Agrarian Law Comprehensive Study, Kencana Prenada Media Group, Jakarta

Interview:

Interview with Mr. Malik Hasyim, the staff of the Registration of Rights and Information of the Cilacap Regency Land Office, April 2, 2021 